\title{
High Resolution Computed Tomography
}

National Cancer Institute

\section{Source}

National Cancer Institute. High Resolution Computed Tomography. NCI Thesaurus.

Code C20644.

Defined as thin section (1-2 mm collimation) CT optimized by using a high-spatialfrequency (bone) algorithm. (from Radiol Clin North Am 1991;29:1043-9) 